\title{
Pendampingan Penggunaan Aplikasi Akuntansi UKM dalam Menyusun Laporan Keuangan
}

\section{Selfira Salsabilla*, Afuan Fajrian Putra, Chivalrind Ghanevi Ayuntari, Yestias Maharani}

Program Studi Diploma 3 Akuntansi, Fakultas Bisnis dan Ekonomika, Universitas Islam Indonesia, Yogyakarta, Indonesia.

${ }^{*}$ Corresponding author: selfirasalsabilla@uii.ac.id

\section{Abstrak}

Kegiatan ini bertujuan untuk mengatasi masalah yang sedang dihadapi oleh pelaku bisnis diindustri pembuatan sprei dan bedcover yang tergabung dalam WA Grup Craft di Yogyakarta. Masing-masing pelaku bisnis yang tergabung dalam WA Grup tersebut memiliki permasalahan yang sama yaitu mengenai kesulitan dalam melakukan pencatatan keuangan. Hal ini berdampak pada belum terpisahnya pencatatan keuangan pribadi dengan usahanya. Sehingga, pelaku bisnis kesulitan dalam menilai apakah hasil usahanya tersebut mengalami keuntungan atau justru mengalami kerugian. Atas dasar permasalah tersebut, dibentuk program pendampingan dalam penyusunan laporan keuangan menggunakan Aplikasi Akuntansi UKM. Aplikasi ini dipilih karena dapat dengan mudah di unduh oleh pengguna menggunakan smartphone. Metode pelaksanaan kegiatan dilakukan dalam bentuk edukasi dan pendampingan dalam penggunaan Aplikasi tersebut. Hasil kegiatan ini menunjukkan respon yang positif bagi para peserta dan para peserta dinilai sudah siap dalam bersaing di era industri 4.0. Namun demikian, berdasarkan hasil evaluasi menunjukan bahwa kegiatan ini perlu dilaksanakan berkelanjutan mengingat terbatasnya waktu saat pendampingan terdapat beberapa peserta yang masih membutuhkan bimbingan lebih lanjut.

Kata kunci: Penyusunan Laporan Keuangan; Aplikasi UMK; Smartphone

\section{Abstract}

This activity aims to overcome the problems that are being faced by business people in the sheet and bedcover manufacturing industry who are members of the WA Craft Group in Yogyakarta. Each of the business people who are members of the WA Group have the same problem, namely the difficulty in carrying out financial records. This has an impact on the not yet separated personal financial records from the business. So, business people have difficulty in assessing whether the results of their business are experiencing profits or actually experiencing losses. On the basis of these problems, a mentoring program was formed in the preparation of financial reports using the SME Accounting Application. This application was chosen because it can be easily downloaded by users using smartphones. The method of carrying out activities is carried out in the form of education and assistance in the use of the application. The results of this activity showed a positive response for the participants and the participants were considered ready to compete in the industrial era 4.0. However, based on the results of the evaluation, it shows that this activity needs to be carried out continuously considering the limited time during mentoring, there are some participants who still need further guidance.

Keywords: Preparation of Financial Statement; UMK Application; Smartphone

Cite this article: Salsabilla, S., Putra, A. F., Ayuntari, C. G., \& Maharani, Y. (2021). Pendampingan Penggunaan Aplikasi Akuntansi UKM dalam Menyusun Laporan Keuangan. Rahmatan Lil'alamin Journal of Community Services, 1 (1). 


\section{Pendahuluan}

Pelaku usaha dalam menjalankan bisnisnya tidak dapat dipungkiri akan terlibat dalam beberapa transaksi yang terjadi atas dilakukannya proses bisnis dalam suatu usaha. Oleh sebab itu, setiap kejadian ekonomi yang terjadi pada perusahaan tersebut hendaklah untuk dilakukan pencatatan. Hasil dari pencatatan tersebut nantinya akan membantu dalam penyusunan laporan keuangan. Laporan keuangan tersebut akan bermanfaat bagi pengguna baik internal maupun eksternal untuk proses pengambilan keputusan. Laporan keuangan tersebut juga merupakan alat pertanggung jawaban manajer atas pengelolaan sumber daya yang dimiliki oleh perusahaan. Laporan keuangan juga memiliki fungsi untuk menilai kinerja keuangan perusahaan apakah baik atau buruk, serta mengetahui posisi keuagan dari perusahaan tersebut.

Proses pencatatan ini semestinya juga dilakukan oleh pelaku usaha kecil mikro menengah (UMKM). Di Indonesia, standar pelaporan keuangan mengacu pada Standar Akuntansi Keuangan untuk Entitas Mikro, Kecil, dan Menengah. Berdasarkan SAK EMKM, pelaku UMKM perlu menyusun setidaknya 3 laporan keuangan, yaitu laporan posisi keuangan pada akhir periode, laporan laba rugi selama periode, dan catatan atas laporan keuangan yang berisi tambahan dan rincian pos-pos tertentu yang relevan (Ikatan Akuntan Indonesia, 2018). Namun, banyak ditemui pelaku UMKM yang belum menyadari pentingnya pencatatan atas setiap transaksi keuangan yang terjadi dalam proses bisnisnya. Beberapa hal yang mempengaruhi persepsi pelaku usaha terkait pentingnya pembukuan dan pelaporan keuangan adalah jenjang pendidikan, latar belakang pendidikan, ukuran usaha, dan lama usaha berdiri (Rudiantoro \& Siregar, 2012). Selain itu, beberapa dari mereka hanya fokus pada pengejaran kuantitas produknya supaya laku terjual tanpa memperhatikan proses pencatatannya. Kendala ini dihadapi salah satunya karena minimnya pengetahuan tentang bidang akuntansi dan terbatasnya sumber daya manusia yang fokus pada pencatatan akuntansinya. Sama hal nya, kendala ini dihadapi oleh beberapa pelaku usaha sprei dan bedcover yang tergabung dalam WA grup Craft. WA grup ini hadir untuk mempermudah berkomunikasi antar pelaku usaha sprei dan bedcover. Mayoritas dari mereka belum melakukan pencatatan atas setiap transaksi yang terjadi dan masih banyak yang mencampurkan antara keuangan pribadi dengan usahanya. Hal ini selaras dengan penelitian yang dilakukan oleh yang (Siagian \& Indra, 2019) menyatakan bahwa pelaku usaha mikro memiliki kendala dalam menyusun laporan keuangan karena pendapatan usaha masih tercampur dengan kebutuhan rumah tangga Hal ini terjadi karena minimnya pengetahuan akuntansi dan keterbatasan waktu.

Oleh sebab itu, tim pengabdian masyarakat membuat sebuah program kegiatan untuk melakukan pendampingan penggunaan aplikasi akuntansi berbasis smartphone. Saat ini, smartphone dapat dikatakan sudah banyak digunakan oleh semua kalangan, termasuk pelaku usaha. Pengembang aplikasi berbasis android telah banyak menghasilkan banyak fitur yang memudahkan para pengguna, seperti fitur keuangan dan media sosial 
(Windayani, Herawati, \& Sulindawati, 2018). Banyak perusahaan swasta yang membuat berbagai aplikasi akuntansi untuk mempermudah pelaku bisnis dalam melakukan pencatatan transaksi usahanya. Beberapa aplikasi misalnya SIAPIK yang dibuat oleh Bank Indonesia; LAMIKRO - Akuntansi Usaha Mikro yang dibuat oleh Kementerian Koperasi dan Usaha Kecil Menengah (UKM), dan beberapa perusahaan swasta juga membuat mobile accounting app seperti Akuntansi UKM, Akuntansiku - Aplikasi Akuntansi Keuangan UKM, Jurnal Mobile, Teman Bisnis - Aplikasi Pencatatan Keuangan Bisnis, dan lain sebagainya (Kholid, 2021). Pada program pengabdian ini aplikasi yang digunakan adalah Akuntansi UKM. Akuntansi UKM dapat digunakan pelaku usaha untuk memenuhi kebutuhan standar pengelolaan sistem informasi keuangan, sehingga pencatatan keuangan perusahaan tersistem dengan baik dan benar untuk meminimalkan resiko kebangkrutan (Hetika \& Faidah, 2020). Aplikasi ini dipilih karena fitur yang disediakan cukup sederhana, sehingga pengguna yang tidak memiliki latar belakang pada bidang pendidikan akuntansi atau pun bisnis dapat menggunakan aplikasi tersebut. Karena basis penggunaan aplikasi ini dapat diakses melalui smartphone masing-masing pengguna, maka hal ini diharapkan dapat mempermudah pelaku usaha untuk segera mencatatat segala macam transaksi tanpa perlu menunda pencatatan.

\section{Metode Pelaksanaan}

WA Grup Craft merupakan perkumpulan pelaku usaha pembuatan sprei dan bedcover yang berada di Yogyakarta. Kegiatan pendampingan penyusunan laporan keuangan menggunakan aplikasi akuntansi UKM ini didampingi oleh tim pengabdian dari dosen Akuntansi Program Diploma III Fakultas Bisnis dan Ekonomika Universitas Islam Indonesia. Pendampingan ini dilaksanakan pada tanggal 7 November 2020 dan bertempat di toko salah satu anggota WA Grup Craft yang beralamatkan di Sonosewu, Ngestiharjo.

Permasalahan yang dihadapi pelaku usaha pembuatan sprei dan bedcover adalah minimnya pengetahuan dalam melakukan pencatatam transaksi. Oleh sebab itu beberapa solusi yang diberikan dalam menangani permasalahan ini adalah sebagai berikut:

1. Memberikan pemahaman mendasar mengenai proses bisnis dan siklus akuntansi secara sederhana.

2. Penjelasan berbagai aplikasi akuntansi berbasis smartphone dan memberikan pengenalan lebih mendalam terhadap penggunaan aplikasi Akuntansi UKM.

3. Memberikan pelatihan dan pendampingan pencatatan akuntansi secara langsung menggunakan aplikasi Akuntansi UKM.

Kegiatan program pengabdian dilakukan melalui beberapa langkah sebagai berikut:

1. Tahap Persiapan. Tahap persiapan dimulai dengan adanya surat permohonan untuk melaksanakan kegiatan pendampingan penyusunan laporan keuangan. Kemudian dibentuk tim pengabdian. 
Tahapan terakhir adalah mengidentifikasi permasalahan yang terjadi pada pelaku usaha.

2. Tahap Pengkajian. Tahap pengkajian adalah tahap dimana tim pengabdian melakukan perumusan program yang sesuai untuk memecahkan permasalahan yang dihadapi pelaku usaha dan metode yang akan digunakan dalam penyampaian materi pengabdian.

3. Tahap Pelaksanaan Program Pengabdian. Tahap pelaksanaan terdiri dari edukasi materi yang sudah disiapkan oleh tim pengabdian dan dilanjutkan dengan praktik langsung penggunaan aplikasi Akuntansi UKM.

4. Tahap Evaluasi Program Pengabdian. Tahap evaluasi dilakukan melalui survei pemahaman dari masing-masing peserta.

\section{Pembahasan}

Pelaksanaan program pengabdian masyarakat ini dilakukan dengan melibatkan empat dosen Akuntansi Program Diploma 3 FBE UII dan beberapa anggota pembuat sprei dan bedcover yang tergabung dalam WA Grup Craft. Program ini bertujuan untuk memberikan pemahaman dasar proses bisnis dan akuntansi, serta pengenalan aplikasi akuntansi berbasis smartphone, yaitu aplikasi Akuntansi UKM.

Aktivitas yang dilakukan dalam kegiatan pengabdian masyarakat adalah sebagai berikut:

1. Tahap Persiapan

Kegiatan pengabdian ini diawali dengan adanya diskusi internal pengrajin sprei yang tergabung dalam WA Grup Craft terkait kendala yang dihadapi yaitu salah satunya adalah pencatatan keuangan sehari-hari. Kemudian, perwakilan dari salah satu grup tersebut, yaitu pemilik toko sprei Roena Rose menginisiasi untuk meminta bantuan dari Tim Pengabdian Diploma 3 Akuntansi untuk membantu memberikan solusi atas kendala yang dihadapi oleh pelaku UMKM yang tergabung dalam grup WA tersebut. Tim beserta perwakilan dari pemilik toko sprei Roena Rose berdiskusi untuk menentukan tanggal dan tempat dilaksanakan pengabdian tersebut. Hasil dari diskusi tersebut ditentukan bahwa pada hari Sabtu, 7 November 2020 akan dilaksanakan pendampingan penggunaan aplikasi Akuntansi UKM. Lokasi kegiatan pengabdian dilaksanakan di toko sprei Roena Rose yang beralamatkan di Jalan Kesejahteraan Sosial 60 A. Kegiatan tersebut dihadiri oleh 8 peserta dari perwakilan WA Grup Craft.

2. Tahap Pengkajian

Pada tahap ini ketua pelaksanan melakukan koordinasi dengan dosen akuntansi lainnya terkait dengan tata pelaksanaan kegiatan pengabdian masyarakat. Hasil dari rapat koordinasi tersebut adalah merumuskan materi yang hendak disampaikan pada saat kegiatan pengabdian berlangsung. Materi tersebut meliputi: 
Table 1. Metode Penyampaian Materi Pengabdian

\begin{tabular}{|c|c|c|c|}
\hline No & Metode & Topik Materi & Sesi \\
\hline 1 & Sosialisasi dan Edukasi & $\begin{array}{l}\text { Proses Bisnis } \\
\text { Pentingnya melakukan pencatatan keuangan } \\
\text { Siklus akuntansi dasar }\end{array}$ & 1 \\
\hline 2 & $\begin{array}{l}\text { Pelatihan dan } \\
\text { Pendampingan }\end{array}$ & $\begin{array}{l}\text { Pengenalan aplikasi akuntansi berbasis smartphone } \\
\text { Pengenalan fitur pada aplikasi akuntansi UKM dan } \\
\text { praktik penggunaan aplikasi }\end{array}$ & 2 \\
\hline 3 & Diskusi & $\begin{array}{l}\text { Mendiskusikan permasalahan yang berkaitan dengan } \\
\text { penggunaan aplikasi akuntansi UKM }\end{array}$ & 3 \\
\hline
\end{tabular}

3. Tahap Pelaksanaan

Tahap pelaksanaan program pengabdian dimulai melalui beberapa sesi sebagai berikut:

a. Sesi 1: Sosialisasi dan Edukasi

Pelaksanaan kegiatan pengabdian masyarakat diawali dengan memberikan pemaham awal mengenai proses bisnis. Dimulai dengan menjelaskan maksud dari proses bisnis, tipe-tipe proses bisnis, manfaatnya bagi perusahaan untuk memahami proses bisnisnya, dan memberikan contoh dari proses bisnis (dalam hal ini proses bisnis perusahaan manufaktur). Setelah memahami terkait proses bisnis, dilanjutkan dengan penjelasan materi mengenai pentingnya melakukan pencatatan keuangan. Dan sesi 1 ditutup dengan pejelasan mengenai siklus akuntansi secara ringkas kepada peserta untuk memberikan gambaran umum bagaimana suatu laporan keuangan dapat disusun.

b. Sesi 2

Pada tahap pelatihan dan pendampingan, tim pengabdian memberikan pengenalan beberapa aplikasi akuntansi berbasis smartphone, misalnya misalnya SIAPIK, LAMIKRO, Akuntansi UKM, Akuntansiku - Aplikasi Akuntansi Keuangan UKM, Jurnal Mobile, Teman Bisnis - Aplikasi Pencatatan Keuangan Bisnis, dan lain sebagainya. Tim juga menjelaskan manfaat yang dapat dirasakan pengguna jika menggunakan aplikasi akuntansi berbasis smartphone. Pada pengabdian kali ini, tim memilih aplikasi akuntansi UKM sebagai alat bantu penyusunan laporan keuangan. Peserta diminta untuk mengunduh aplikasi UKM melalui Play Store menggunakan smartphone masing-masing. Peserta diberikan penjelasan mengenai fitur-fitur yang ada dalam aplikasi tersebut, dimulai dengan pembuatan identitas usaha, menjelaskan secara ringkas beberapa akun, pembuatan neraca saldo awal, proses penginputan berbagai macam transaksi, menampilkan laporan yang dihasilkan atas input yang sudah dilakukan, hingga proses bagaimana cara mengunduh laporan yang sudah dibuat. Setelah memahami fitur-fitur yang ada dalam aplikasi tersebut, tim pengabdian mendampingi masing-masing peserta untuk mencoba melakukan input data transaksi. Gambar 1 menyajikan gambar pelaksanaan kegiatan penggunaan aplikasi Akuntansi UKM. 


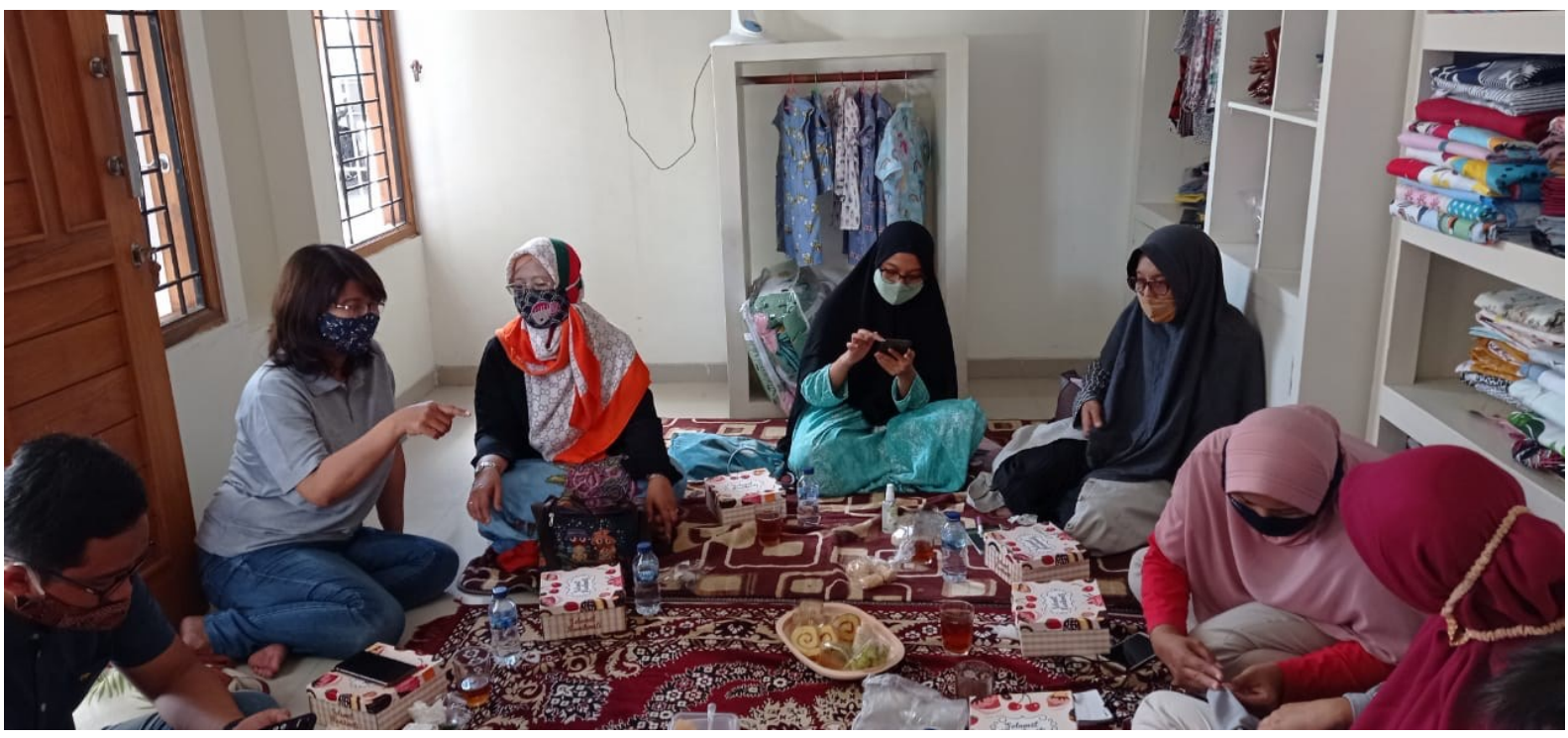

Gambar 1. Kegiatan saat mengaplikasikan Akuntansi UKM

c. Sesi 3

Sesi ketiga adalah sesi dimana para peserta yang sudah diberikan pendampingan penggunaan aplikasi akuntansi UKM untuk mendiskusikan permasalahan yang berkaitan dengan penggunaan aplikasi tersebut. Kemudian, tim pengabdian memberikan solusi atas permasalahan yang disampaikan peserta.

4. Tahap Evaluasi

Setelah menyelesaikan serangkaian tahapan dimulai dari sosialisasi, edukasi, pelatihan, dan pendampingan, tahap terakhir dari program pengabdian adalah melakukan evaluasi untuk mendapatkan umpan balik dari program tersebut. Evaluasi dilakukan dengan melakukan pengisian kuesioner.

\section{Kesimpulan}

Pelaksanaan kegiatan "Pendampingan Penggunaan Aplikasi Akuntansi UKM dalam Menyusun Laporan Keuangan" bagi pelaku usaha sprei dan bedcover dapat berjalan dengan lancar. Kegiatan ini dihadiri oleh 8 pelaku usaha yang terdaftar dalam WA Grup Craft. Pada kegiatan tersebut para pelaku usaha langsung mempraktikkan penggunaan aplikasi Akuntansi UKM. Aplikasi ini dapat digunakan sebagai salah satu media untuk mengatasi kendala yang dihadapi oleh pelaku usaha, karena aplikasi ini dapat digunakan melalui smartphone. Keberhasilan kegiatan ini dapat diukur melalui $75 \%$ peserta memiliki kesadaran untuk melakukan pencatatan dan didukung dengan pemahaman akan proses bisnis, 50\% peserta sudah mengenal beberapa aplikasi akuntansi berbasis smartphone sebelumnya, dan 75\% peserta yang dapat mengaplikasikan aplikasi akuntansi UKM dengan baik setelah diberikan pendampingan.

Saran untuk kegiatan pendampingan berikutnya adalah pendampingan penyusunan laporan keuangan dengan bantuan aplikasi akuntansi UKM hanya menjelaskan beberapa fitur yang dapat digunakan oleh para pelaku 
usaha dan hanya menyajikan beberapa contoh transaksi yang biasanya terjadi. Sehingga, data yang diinput oleh masing-masing pelaku usaha belum mencerminkan kondisi keuangan dari usaha masing-masing peserta. Diharapkan kedepannya dapat diselenggaran kembali untuk melakukan pendampingan penginputan transaksi dimulai penentuan neraca saldo awal dan penginputan transaksi untuk periode waktu tertentu kepada para pelaku usaha tersebut secara individu.

\section{Referensi}

Hetika, \& Faidah, Y. A. (2020). Aplikasi Akuntansi Berbasis Android Untuk Menyusun Laporan Keuangan pada UMKM (Studi Kasus pada Usaha Konveksi “Very Convection”). Jurnal MONEX, 9(1).

Ikatan Akuntansi Indonesia. (2018). Standar Akuntansi Keuangan Entitas Mikro, Kecil, dan Menengah.

Kholid, M. N. (2021). Mobile Accounting App Untuk Meningkatkan Kualitas Laporan Keuangan UMKM. Retrieved from fecon.uii.ac.id website: https://fecon.uii.ac.id/blog/2021/03/26/mobile-accounting-appuntuk-meningkatkan-kualitas-laporan-keuangan-umkm/

Rudiantoro, R., \& Siregar, S. V. (2012). Kualitas laporan keuangan UMKM serta prospek implementasi SAK ETAP. Jurnal Akuntansi Dan Keuangan Indonesia, 9(1).

Siagian, A. O., \& Indra, N. (2019). Pengetahuan Akuntansi Pelaku Usaha Mikro Kecil dan Menengah (UMKM) Terhadap Laporan Keuangan. Jurnal Ilmiah Indonesia, 4(12).

Windayani, L. P., Herawati, N. T., \& Sulindawati, L. G. E. (2018). Analisis Penerapan Aplikasi Akuntansi Berbasis Andorid LAMIKRO untuk Membantu Usaha Mikro Kecil Menyusun Laporan Keuangan Sesuai SAK EMKM (Studi Pada Toko Bali Bagus). Jurnal IImiah Mahasiswa Akuntansi, 9(3). 